\title{
PENGALAMAN MASYARAKAT SEBAGAI PENOLONG AWAM DALAM MEMBERIKAN PERTOLONGAN KEPADA KORBAN KECELAKAAN LALU LINTAS KABUPATEN BOJONEGORO
}

\author{
Bayu Akbar Khayudin \\ Prodi IImu Keperawatan \\ STIKes Insan Cendekia Husada Bojonegoro, bayuakbarbojonegoro@gmail.com
}

\begin{abstract}
ABSTRAK
Fenomena pemberian pertolongan pertama di tempat kejadian pada korban kecelakaan lalu lintas jarang dilakukan langsung oleh petugas kesehatan ataupun masyarakat sekitar lokasi kejadian sebagai orang yang terlatih. Orang awam yang sering dijumpai dan memberikan pertolongan pertama adalah Masyarakat.

Tujuan penelitian ini yaitu untuk mengeksplorasi makna pengalaman masyarakat sebagai orang awam dalam menolong korban kecelakaan Lalu lintas di Kabupaten Bojonegoro. Desain penelitian kualitatif dengan pendekatan fenomenologi intepretatif. Pengumpulan data menggunakan metode wawancara mendalam dengan panduan wawancara semi terstruktur yang melibatkan empat partisipan.

Hasil penelitian ini mendapatkan 3 tema : (1) Menolong Korban Dengan Semampunya (2) Merasakan ketakutan saat menolong korban (3) Berharap adanya kerjasama dengaan tim penolong dalam menjalankan system pertolongan korban kecelakaan.

Kesimpulan penelitian ini yaitu masyarakat mengharapkan adanya kerja sama tim penolong dalam menjalankan system pertolongan korban kecelakaan. pelatihan serta kemudahan dalam menghubungi petugas sangat diharapkan oleh masyarakat untuk menyelamatkan korban kecelakaan lalu lintas dengan kemampuan yang lebih baik.
\end{abstract}

Kata Kunci : Orang Awam, Menolong, Masyarakat, Korban, Kecelakaan

\section{ABSTRACT}

The phenomenon of providing first aid at the scene to victims of traffic accidents is rarely done directly by health workers or the community around the scene as trained people. Lay person who are often found and provide first aid is the Community.

The purpose of this study is to explore the meaning of community experience as lay person in helping victims of traffic accidents in Bojonegoro. Qualitative research design with interpretative phenomenological approach. Data collection uses in-depth interviews with a semi-structured interview guide involving four participants.

The results of this study get 3 themes: (1) Helping Victims With As Good As They Can (2) Feeling fear while helping victims (3) Hoping for cooperation with the relief team in carrying out the accident victim's rescue system.

The conclusion of this study is that the community expects the assistance of teamwork in carrying out a system of assistance for accident victims. training and ease in contacting officers are highly expected by the community to save victims of traffic accidents with better skills

Keyword : Layperson, Help, Community, Victim, Accident

Jurnal IImu Kesehatan MAKIA, Vol.10 No.2, Agustus 2020

$$
\text { E - ISSN: 2549-9327, P - ISSN : 2407-6309 }
$$




\section{PENDAHULUAN}

Kecelakaan merupakan salah satu penyebab kematian utama yaitu mencapai setengah dari seluruh kematian di dunia (Hadi, 2010). data laka lantas yang ada di Polres Bojonegoro dari tahun 2011 sampai 2015 jumlah kejadian kecelakaan lalu lintas mencapai 2.852 kasus dengan jumlah korban 6381 jiwa. Data korban meninggal dunia kecelakaan mencapai $(10,7 \%)$ jiwa, korban luka berat $(3,8 \%)$ jiwa, korban luka ringan mencapai $(85,4 \%)$ jiwa. Pengumpulan data selama tahun 2016 mencapai 924 kasus dengan jumlah korban 1.893 jiwa. Data korban meninggal dunia sebanyak $(6,6 \%)$ jiwa, korban luka berat $(2,8 \%)$ jiwa, korban luka ringan $(91,1 \%)$ jiwa.

Tingginya angka kecelakaan lalu lintas berdampak diperlukannya pertolongan yang cepat dan tepat di tempat kejadian demi mencegah terjadinya morbiditas dan mortalitas pada korban kecelakaan lalu lintas (Elmqvist, et al 2010). First aid pada kejadian kecelakaan harus dilakukan di tempat kejadian sebagai proses prehospital care. First aid pada kejadian kecelakaan harus dilakukan di tempat kejadian sebagai proses prehospital care. Respon time yang bergantung pada tiga komponen, yaitu waktu pemrosesan panggilan, waktu yang dipergunakan tim di ambulan untuk bersiap, dan waktu perjalanan ke lokasi kejadian menjadi lebih lama karena komunikasi yang buruk, sumber daya tidak terlatih, dan kemacetan lalu lintas di jalan utama kota besar yang menjadi hambatan petugas EMS dalam menolong korban (Hisamuddin, et al, 2007).

Fenomena pemberian first aid di tempat kejadian pada korban kecelakaan lalu lintas di negara Indonesia, khususnya di Kabupaten Bojonegoro jarang dilakukan langsung oleh petugas kesehatan. Orang yang pertama menemukan korban kecelakaan sebelum petugas kepolisian serta petugas kesehatan datang adalah masyarakat (Khayudin.,B.A, et al 2018).
Masyarakat Indonesia sebenarnya memiliki rasa ingin menolong ketika melihat kecelakaan lalu lintas. Akan tetapi pengetahuan, keterampilan serta kebiasaan yang belum ada, membuat masyarakat berat untuk menolong bahkan hanya diam. Masyarakat kurang bisa memahami bagiaman pelaksnaan petolongan pertama khususnya bantuan hidup dasar (Khayudin B,A \& Maslichah, 2016).

\section{METODE PENELITIAN}

Metode penelitian yang digunakan dalam penelitian ini adalah metode penelitian kualitatif dengan pendekatan fenomenologi interpretative. Jumlah partisipan dalam penelitian ini adalah 5 partisipan. Pengumpulan data dilakukan dengan wawancara mendalam (indepth interview) menggunakan panduan wawancara semi terstruktur (Afiyanti, Y. dan Rachmawati, N.I. 2014).

Selama wawancara peneliti juga menggunakan catatan lapangan (field note). Setelah data terkumpul peneliti menggunakan proses Analisa data Interpretative Phenomenological Analysis (IPA) Jeong, H. and Othman, J,. 2016. tempat penelelitian wilayah Sukoharjo Kecamaan Kalitidu Kabupaten Bojonegoro Provinsi Jawa Timur, Provinsi jawa Timur, Negara Republik Indonesia.

\section{HASIL DAN PEMBAHASAN \\ Tema 1 : Menolong Korban Dengan Semampunya \\ Menceritakan tindakan yang} dilakukan masyarakat sebagai orang awam dalam menolong korban kecelakaan lalu lintas

"kita bawa ke tepi kalau tidak parah ya ..kita kasih minum dulu, kita kasih air minum dulu biar tidak kaget, terus mungkin kalau luka luka kecil kita tolong, kita kasih obat merah"

"Teman saya sendiri, kakinya patah. Kan saya angkat, woohh, ini kakinya patah terus 
saya ambil kaya bidai itu. Kayu yang bisa menopang saya tali"

Respon tindakan pertolongan pertama yang sering dilakukan masyarakat adalah memberikan air minum pada korban kecelakaan. Hal ini sangat berbahaya jika korban kecelakaan mengalami aspirasi sehingga terjadi sumbatan jalan nafas (Lieser \& Alexis. 2009). Peran penolong menurut Kureckova (2016) adalah menekan faktor yang dapat menyebabkan gangguan kesehatan serta kehilangan nyawa pada kejadian kecelakaan (Kureckova, et al 2016). Oleh karena itu meskipun masyarakat sudah melakukan tindakan pertolongan pertama akan tetapi tidak bisa memberikan sesuai standar.

\section{Tema 2 : Merasakan ketakutan saat menolong korban}

Menceritakan bagaimana perasaan masyarakat menjadi orang awam dalam menolong korban kecelakaan lalu lintas

"Karena saya nggak berani s ebelum polisi datang"

"tidak berani melihat orang kecelakaan yag parah"

Redman 2006 menyatakan bahwa penolong pertama dalam menghadapi korban dengan kondisi yang gawat darurat berada dalam kondisi yang penuh ketegangan dan stress. penolong pertama yang menjadi pertama dilokasi kejadian dengan apapun kondisinya, keselamatan korban menjadi yang utama. Jadi dalam kondisi perasaan apapun, kesiapan penolong dalam bentuk apapun, prioritas utama tetaplah keselamatan korban kecelakaan lalu lintas (Elmqvist, 2010).

\section{Tema : Berharap adanya kerjasama dengaan tim penolong dalam menjalankan system pertolongan korban kecelakaan}

Menceritakan harapan masyarakat tentang bagaimana sistem menolong korban kecelakan yaitu adanya kerjasama dengaan tim penolong dalam menjalankan system pertolongan korban kecelakaan

"Untk tenaga medis harapannya untuk segera, tapi saya sulit untuk menghubungi itu. Harus menghubungi kemana"

"Ya, diberikan pelatihan, jadi misalnya untuk menolong korban yang kakinya patah, atau tidak sadarkan diri itu bagaimana"

first responder dalam pengalamannya membutuhkan kerjasama lintas sector (Elmqvist, 2010).

Pelayanan prehospital akan diberikan setelah ada informasi yang diterima oleh operator yang ada di Rumah Sakit. Pusat komunikasi ini berada di IGD Rumah Sakit (Lieser \& Alexis, 2009). Menurut Wilde (2009) membuktikan secara jelas tentang pentingnya waktu tanggap (respon time) yaitu dapat menentukan keluasan rusaknya organ bahkan dapat mengurangi beban pembiayaan korban ketika di Rumah sakit. Oleh karena itu kerjasama tim kesehatan dengan kepolisian serta masyarakat harus dibentuk dengan baik. Supaya korban kecelakaan dapat tertangani dengan baik dan meningkatkan derajat hidup korban keelakaan.

\section{KESIMPULAN}

Masyarakat menyadari bahwa Tindakan yang dilakukan masyarakat sebagai orang awam dalam menolong korban kecelakaan lalu lintas adalah Menolong Korban Dengan Semampunya. Karena pada saat menolong korban kecelakaan lalu lintas masyarakat sebagai orang awam merasakan ketakutan saat menolong korban.

Sehingga masyarakat sebagai orang awam dalam menolong korban kecelakaan lalu lintas berharap adanya kerjasama dengaan tim penolong dalam menjalankan system pertolongan korban kecelakaan. 


\section{DAFTAR PUSTAKA}

Afiyanti, Y. dan Rachmawati, N.I. 2014. Metodologi Penelitian Kualitatif Dalam Riset Keperawatan, Edisi 1. Rajawali Pers, Jakarta

Polantas Bojonegoro. 2017. Data Lakalantas Kabupaten Bojonegoro Tahun 2011-2017

Elmqvist.,C, Brunt D., Fridlunt D \& Eksberg M. 2010. Being first on the scene of an accident-experiences of doing prehospital emergency care. Journal complication nodic of caring science.,24.266-273

Hadi,J.P. 2010. Gawat Darurat. Jakarta : EGC

Hisamuddin, Hamzah MS, Holliman CJ. 2007. Prehospital Emergency Medical Services in Malaysia. International Emergency Medicine.; 32(4):415-21

Jeong, H. \& Othman, J,. 2016. Using Interpretative Phenomenological Analysis from a Realist Perspective. The Qualitative Report 21(3): 558570.

Khayudin, B. A \& Maslichah. 2016. Efektifitas Demonstrasi Basic Life Support (Bls) Terhadap Kemampuan Masyarakat Dalam Memberikan Pertolongan Pertama Korban Laka Lantas Di Desa Pumpungan Kalitidu Bojonegoro. Jumakia Vol.3 No.1. DOI: 10.37413/jmakia.v3i1.24

Khayudin.,BA.,Ratnawaty.,R.,\& Astari, A.M.,2018. The police experience as bystander in giving first aid to traffic accident in the district bojonegoro : phenomenological study. World journal of advance healthcare research. volume2, issue 5.2018 page :76-80. ISSN : 2457-0400
Kureckova, V., Gabrhel, V.,Zamecnik, P.,Rezac, P., Zaoral, A., Hobl, J,. 2016. First aid as an important traffic safety factor evaluation of the experience-based training. Transport Research Centre, Brno, Czech Republic. DOI 10.1007/s12544-0160218-4

Lieser \& Alexis. 2009. Perspective on Emergency Medical Services in Bali. Western Journal of Emergency Medicine. Department of Emergency Medicine: UC Irvine.2334-2354

Redman, P. 2006. Nursing Research Principles And Methodes $7^{\text {th }}$ Ed. Philadelphia :Lippincott Walker \& Wikkin 